\title{
Determinants of Non-Performing Loans for the EEC Region. A Financial Stability Perspective
}

\author{
Luminita Roxana TATARICI \\ Bucharest University of Economic Studies, Bucharest, Romania \\ luminitatatarici@gmail.com \\ Matei Nicolae KUBINSCHI \\ Bucharest University of Economic Studies, Bucharest, Romania \\ matei.kubinschi@bnro.ro \\ Dinu BARNEA \\ Bucharest University of Economic Studies, Bucharest, Romania \\ dinu.barnea@bnro.ro
}

\begin{abstract}
This article investigates the determinants of non-performing loans for a panel of EEC countries and the implications for the real economy, covering the period 2005-2017. Among the determinants, the paper proposes macroeconomic factors, banking sector variables, and cost and governance indicators. Additionally, the paper explores the extensive use of macroprudential measures in these countries. Using a panel with fixed effects and a dynamic GMM estimator, the results support the existing findings that adverse macroeconomic developments are generally associated with higher non-performing loans, while increases in NPLs have a rather transitory effect on the real economy and credit. NPL ratios increase if macroeconomic conditions deteriorate, while an improvement in the government effectiveness reduces them. A more profitable and better capitalized banking sector generally leads to lower NPLs. Moreover, countries with higher past credit growth rates witnessed higher NPLs in the periods that followed. These results support the use of macroprudential measures for increasing the resilience of borrowers, such as limits on the indebtedness level (such as debt serviceto-income, DSTI or loan-to-value, LTV caps), as tools to temper the credit cycle.
\end{abstract}

Keywords: non-performing loans, financial stability, credit growth, macroprudential policy.

Please cite the article as follows: Tatarici, L. R., Kubinschi, M. N., Barnea, D. (2020), "Determinants of Non-Performing Loans for the EEC Region. A Financial Stability Perspective", Management \& Marketing. Challenges for the Knowledge Society, Vol. 15, No. 4, pp. 621-642, DOI: $10.2478 / \mathrm{mmcks}-$ 2020-0036.

\section{Introduction}

In the post-global financial crisis environment (GFC), credit risk remained one of the main contributors to the systemic risk ${ }^{1}$. The large volumes of non-performing loans pose major challenges for the banking sector and have negative implications for the economic recovery.

\footnotetext{
${ }^{1}$ Systemic risk is "a risk of disruption in the financial system with the potential of having serious negative consequences for the internal market and the real economy" (Regulation 1092/2010).
} 
Ari et al. (2019) show that for half of the crisis experienced since 1990, the non-performing loan ratios (NPLs) more than doubled compared to the pre-crisis period. Additionally, they find that if NPLs normally follow similar paths during upturns, this was not the case during the resolution and the longer the time to resolve the large volumes of NPLs, the lower the output.

The macroprudential regulation gained ground in this environment and several instruments were put at work with the aim to maintain financial stability and prevent the accumulation of vulnerabilities. Macroprudential instruments work by enhancing financial institutions or debtors' resilience to risks and some of them are linked with the credit cycle (such as the countercyclical capital buffer), aiming at creating buffers in good economic times to support the downside of the cycle. A close monitoring of lending dynamics and credit risk is therefore important.

There is a common knowledge that links the non-performing loans to the economic cycle, but a lot of research has been carried on in respect to banking sector characteristics and their impact on NPLs also. This article assesses the links between NPLs and the economic environment, while also accounting for banking sector characteristics and prudential regulation.

It aims at contributing to the existing literature in the following ways. Firstly, it analyses a sample of EEC countries, complementing the scarce literature focusing on this group (Skarica, 2013; Klein, 2013; Jakubik \& Reininger, 2014). This selection is relevant considering the importance of the banking sector in these countries and the impact of the performance of sectors on the economic growth (Zeqiraj et al., 2020). Additionally, this group of countries experienced large capital inflows after 2000s, driven mainly by the large number of EU subsidiaries, which translated into important lending dynamics and led to the development of their banking sector, but also to an accumulation of vulnerabilities. Secondly, the coverage of an entire credit cycle ${ }^{2}(2005-2017)$ is a novelty facilitating the evaluation of the pro-cyclicality of the financial system and the implications of the GFC in terms of lending and quality of portfolios. In addition, these countries experienced relatively similar credit booms after the 2000s, due to different factors compared to western peers, such as the EU transition process. Thirdly, it highlights the extensive use of prudential regulation (such as limits on DSTI and LTVs) of the countries analysed to curve excessive lending, instruments scarcely used by western countries before the establishment of the macroprudential framework in 2010.

The rest of the paper is organized as follows. Section 2 briefly presents the existing literature. Section 3 presents the data and some preliminary statistics. Section 4 describes the empirical specifications and the results, while Section 5 draws the conclusions.

\section{Literature Review}

The relationship between NPLs and macroeconomic factors was extensively studied in the literature, starting from the underlying assumption of the pro-cyclicality of the financial system. Some lending booms lead to the accumulation of vulnerabilities during upturns,

\footnotetext{
${ }^{2}$ Although the literature on financial cycles generally points to a longer duration compared to business cycles (4 times longer according Detken et al., 2014), this is normally not the case for most of the economies included in the analysis, which witnessed the development of their banking systems after the 2000s.
} 
which materialize in NPLs during downturns. They can end up in banking crises and affect the economic recovery, depending on their length and strength (Ari et al., 2019; Claessens, et al., 2011). Credit dynamics matter, therefore there is a need for a proper monitoring of lending and enforcement of macroprudential measures in a preventive manner with a view to ensure sustainable lending.

The majority of studies highlight the relevance of the macroeconomic environment and lending standards in explaining the quality of banking loans for both developed and emerging economies. Even though the impact seems to differ in terms of amplitude, the results point to the same direction: decreasing or slower economic growth, high unemployment, a depreciation of the local currency or increase in costs can lead to higher NPLs. Jiménez and Saurina (2006) emphasize the negative effects of rapid credit growth under lax credit standards during boom periods and provide empirical evidence on the relationship between rapid credit growth and NPL ratios.

Espinoza and Prasad (2010) investigate the determinants of NPLs for 80 countries in the Gulf Cooperation Council, over 1995 - 2008. They find that slow economic growth, high interest rates and risk aversion, as well as previous credit dynamics contribute to increases in NPL ratios. Beck et al. (2013) perform a similar analysis for a panel of 75 countries, using a panel fixed effect model and a dynamic estimator. For countries with high foreign exposures, when controlling for cost factors, they notice that the balance sheet channel prevails over the competitiveness channel. Beaton et al. (2016) use a sample of countries from the Eastern Caribbean Currency Union and show that macroeconomic factors at both national and global level, together with bank-specific indicators, explain the deterioration in the portfolio quality. Nkusu (2011) points that NPL increases can lead to an adverse spiral, with negative effects on the macroeconomic dynamics, followed by a further deterioration in the banking system, dynamics that reinforce each other. Maciej et al. (2015) present various strategies that banks might employ in dealing with the accumulation of nonperforming exposures, depending on the structure of NPL portfolios, conditions in the real estate market, the composition of the financial sector, the possibility of the establishment of an asset management company and more.

Several studies were also conducted for countries in Central Eastern and SouthEastern Europe. Skarica (2014) analyses the NPL ratios developments in 7 EEC countries and finds that the most important factor is the economic decline. She also provides an insightful outline of the banking sector developments after the countries' transition to EU, such as the high foreign banking ownership and the importance of capital inflows. Jakubik and Reininger (2014) find that, besides economic growth, credit growth matters, as well as the share of foreign currency loans. Klein (2013) proposes a microeconomic approach and evaluates the NPL dynamics for the top ten banks in 16 countries in CESEE over 1998-2011. They show that the higher the unemployment rate, the currency depreciation and inflation, the higher the NPL ratios. Higher global risk aversion (VIX) was also found to generate an increase of NPLs. Anastasiou et al. (2016) differentiate between core and periphery Euro area countries and find that, despite being affected by the same macroeconomic and bankspecific variables in both categories, NPLs respond much softer to changes in macroeconomic conditions in peripheral countries (GIIPS). Fell et al. (2016) and Fell et al. (2017) focus on the mechanics of secondary NPL markets, analysing indicators of market failure which impede their efficient functioning and follow up with policy recommendations for alleviating these deficiencies. 
The results regarding the role of banking sector variables are mixed. Klein (2013) finds evidence for the bad management hypothesis, showing that equity-to-asset ratio and return on equity are negatively correlated with NPLs, while excessive lending leads to higher NPLs. Ari et al. (2019) also find evidence of bad credit booms, showing that in countries with high pre-crisis credit growth rates, NPLs reach peak latter. However, Messai and Jouini (2013) find no relationship between bank lending and NPLs, for three European countries over 2004-2008. Louzis et al. (2012) and Gosh (2015) study the effect of bank soundness indicators for a panel of banks in Greece and USA respectively. Gosh (2015) finds evidence for the moral hazard hypothesis, in the sense that banks with higher profitability do not engage in risky lending. They also show that better capitalized banks, as well as large banks are not as prudent (too big to fail) and face higher NPLs. Louzis et al. (2012) analyse a sample of 9 of the largest Greek banks and different types of loans (consumer, mortgage and business loans). They do not find evidence for the moral hazard or diversification theories, and the bad management hypothesis is found relevant for households' loans only. Accornero et al. (2017) show that, although bank lending is not necessarily affected by the level of NPL ratios, it can be impaired by the over-accumulation of new NPLs and the subsequent increase in provisions.

The role of governance on the dynamics of NPLs has not been widely addressed so far. However, for the sample of countries included in this paper, such indicators are relevant considering that most of them ranked in top 15 lower values among EU countries. Anastasiou et al. (2019) study the impact of an aggregate measure for governance on the NPL ratios for the Greek banking sector over 1996-2006. Ari et al. (2019) use as a proxy for institutional strength the GDP per capita, anticipating that a strong institutional framework will work in two directions. Firstly, it should lead to a smaller increase in NPLs during banking crisis and secondly, it will contribute to a timely NPL resolution. They document a negative and significant contribution for the first aspect for the analysed countries, however the results do not hold for the European countries in relation to the GFC. Bayar (2019) makes a good overview of the findings in the literature on NPLs and also finds evidence for the positive role of a better institutional framework on NPLS.

The literature on the effectiveness of macroprudential regulation is generally focusing on the impact on lending dynamics and only recently on the quality of loans. Neagu et al. (2015) analyse the impact of the macroprudential measures adopted in Romania (LTV and DSTI limits) on the quality of banks' portfolios and find that loans granted when prudential regulation was eased are more sensitive to macroeconomic shocks.

\section{Data and Preliminary Statistics}

The paper covers an entire credit and business cycle spanning over 2005-2017 for 12 EEC countries. The timeframe and selection of countries is constrained by data availability for non-performing loans, banking sector indicators and those for the institutional framework. Mainly, the lack of harmonization and availability for NPL ratios prior to 2008 substantially shortens the pre- crisis period ${ }^{3}$. Due to these constraints, the dataset used has a mixed

\footnotetext{
${ }^{3}$ Against this backdrop, the publication by the European Banking Authority (EBA) of the FINAL draft "Implementing Technical Standards on Supervisory Reporting on Forbearance and Non-Performing Exposures" increased the comparability among countries.
} 
frequency: quarterly and annual. The following countries are included in the analysis: Bulgaria, Croatia, Czech Republic, Estonia, Hungary, Poland, Romania, Latvia, Lithuania, The Republic of Serbia, Slovakia and Slovenia.

\section{Non-performing loan ratios}

The aggregate non-performing loan ratio (NPL ratio) represents the share of nonperforming loans, generally 90 days past due loans, to total amount of loans granted to the private sector (households and non-financial companies) ${ }^{4}$.

The NPL ratio is used as a credit risk indicator, but the following caveats should be kept in mind. Firstly, there are differences in the national definitions of the non-performing loans ${ }^{5}$, but none for the analysed period. Secondly, there is a potential downward bias induced by the ever-greening policies, such as externalization or restructuring of overdue loans. Some of the bias is accounted for by identifying the periods when impaired household loans were sold. Despite these challenges, monitoring and assessing the health of the banking sector is a fundamental aspect for maintaining financial stability.

The developments of the NPL ratios show a similar pattern: a constant increase after 2008 (Figure 1), accompanied by a deterioration of the macroeconomic environment, then followed by an improvement as from 2013. Nevertheless, there is significant heterogeneity among countries, especially regarding the dynamics of the aggregate NPL ratios for the private sector. The values range from a minimum of $0.2 \%$ in 2005 to a peak of $24 \%$, with the majority of countries crossing the 7\% threshold proposed by Ari et al. (2019). The resolution of NPLs was relatively slow, some countries returning to pre-crisis levels only by the end of the period, pointing to an important persistency. In the opposite direction, substantial credit dynamics prior to the crisis (Figure 1, Annex 1) indicates an accumulation of debt.

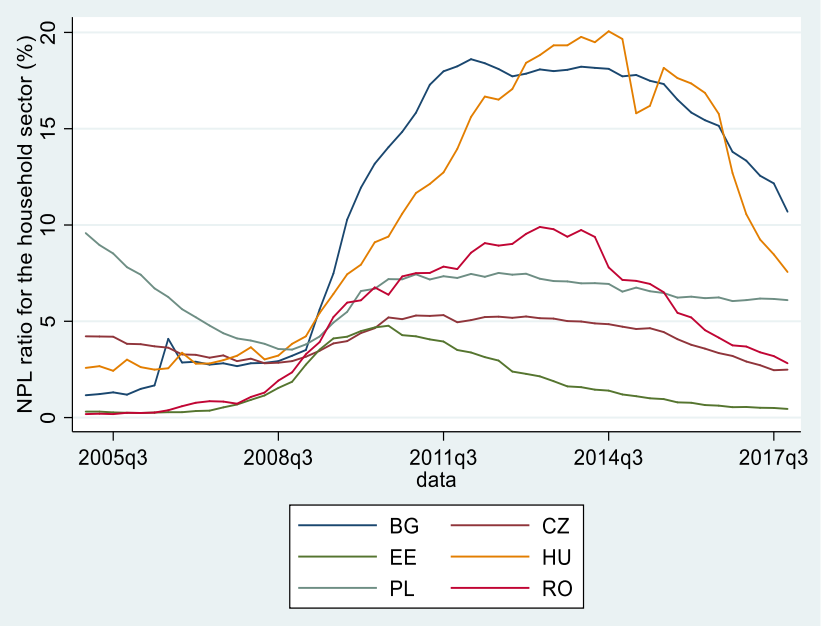

(a) NPL ratio for the household sector*



(b) NPL ratio for the private sector

Figure. 1. NPL ratio developments

\footnotetext{
${ }^{4}$ Financial soundness indicators (IMF).

${ }^{5}$ For example, for Poland and the Czech Republic, the NPL ratio is the sum of substandard, doubtful and loss loans to total loans granted to households, while for Bulgaria the NPL ratio for the household sector includes the restructured loans as well.
} 
Note: *data is available with a quarterly frequency Source: central banks' websites, World Bank Global Financial Development

\section{Variables affecting non-performing loans}

The paper aims in the first place at identifying the determinants of the NPL ratios for the private sector (households and non-financial companies). For this, we use the following categories of variables: macroeconomic factors, banking sector variables and governance indicators. Control variables for the sale of loans are used and also prudential regulation is evaluated. The variables were selected based on the findings from the literature (Louzis et al., 2012; Beck, 2013; Jakubík \& Reininger, 2014; Gosh, 2015; Anastasiou et al., 2019) and data availability. Some summary statistics are presented in Table 1 (Annex 1).

For the first approach, the use of the macroeconomic factors is justified by the assumption of pro-cyclicality in the financial sector: lending increases in good economic times when credit risk is low, while during downturns debtors' repayment capacity is expected to deteriorate and NPL ratios to increase. We use the following indicators: real GDP growth rate, unemployment, inflation and exchange rates.

For bank related variables, we follow the approach in the literature and test several hypotheses:

- Keeton's (1999) lax credit standards hypothesis states that if banks increase the supply of loans in an unsustainable manner, maybe by an easing of credit standards, this could eventually lead to higher NPL ratios (Gosh, 2015; Pesola, 2015). Additionally, Pesola (2007) tested the idea that external shocks can be amplified by over-indebtedness. We use credit to GDP and credit growth rates ${ }^{6}$ to evaluate this hypothesis and we anticipate a positive contribution.

- Two theories are associated with the level of capitalization: (i) the moral hazard hypothesis proposed by Berger and DeYoung (1997) suggesting that banks with low capitalization tend to enter the risky borrowing business, therefore anticipate an inverse relationship between equity capital and NPLs, and (ii) the moral hazard of too big to fail theory, stating that highly capitalized banks can resort to risky activities since they expect government protection.

- In terms of efficiency or profitability, the bad management hypothesis of Berger and DeYoung (1997) imply that less profitable banks will probably invest in risky activities and will witness an increase in NPLs in the future. As such, a negative sign is expected for profitability indicators. However, at the expense of short term profitability, banks can also look into more risky but profitable businesses, which might end up in higher NPLs (Gosh, 2015).

For the institutional factors, the governance effectiveness and regulatory quality indicators ${ }^{7}$ are used. They reflect the perceptions on several types of public services and on governments' ability to implement sound policies and regulations supporting the private

\footnotetext{
${ }^{6}$ Credit to GDP is the standard indicator proposed by BIS for assessing the financial cycle dynamics and also for calibrating the countercyclical capital buffer, CСyB (Guidance for national authorities operating the countercyclical capital buffer, December 2010).

7 The Worldwide Governance Indicators, World Bank. The indicators reflect the perceptions of the economic agents surveyed (enterprises, citizens and expert survey respondents).
} 
sector development. It is expected that a deterioration of these indicators will favour an increase in NPLs. For the analysed countries, the values of governance indicators rank them among the last in the EU.

In addition to these factors, we control for prudential regulation and the sales of loans. They are specified as dummy variables and defined as following:

(i) the dummy regulation accounts for national prudential measures related to household lending 8 . It takes the value of 1 in the quarter when the regulation was introduced/tightened, -1 when it was eased/eliminated and 0 otherwise. We use a cumulative quarterly index (like Cerutti et al., 2017) and also test only for the tightening/introduction of the measures.

(ii) the dummy sales controls for the selling of NPLs, a relevant aspect in the postGFC environment ${ }^{9}$. The NPL transactions trended dynamically after 2015 in EEC countries $^{10}$. The dummy takes the value 1 when there is information on the sale of loans and 0 otherwise, it does not account for the value of the sale, nor is weighted with the face value of the loans, due to lack of information reported. The variable is constructed using the data from the NPL Monitor on the sales of household and corporate portfolios since 2015.

\section{Empirical Specifications and Results Empirical specifications}

The paper is structured in two parts. In the first part, we aim at identifying the factors explaining the NPL dynamics (NPL drivers) and in the second part, at assessing the feedback effects from the banking sector to the real economy and credit dynamics.

For the first part, the assessment of NPL drivers, we use a panel model with fixed effects and a dynamic generalized method of moments (GMM model).

We start from a baseline specification (eq.1), on top of which several variables are added (eq. 2 and 3). All estimates are carried out at country level.

$$
\begin{aligned}
& Y_{i, t}=\alpha+\beta_{1} Y_{i, t-1}+\beta_{2} \Delta \text { Macro }_{i, t}+\beta_{3} \Delta \text { Uncertainty index }_{i, t}+\beta_{4} \text { Dummy sales }_{i, t}+ \\
& \mu_{i, t}+\varepsilon_{i, t}
\end{aligned}
$$

where: $Y_{i, t}=\log \left(\frac{N P L_{i, t}}{\left(1-N P L_{i, t}\right)}\right)$ the logit transformation of the NPL ratio for the country $i$ at the $t$ moment (odds ratio). The existing literature highlights the high persistency in NPL ratios (Klein, 2013; Gosh, 2015; Aria et al., 2019), for which we use the lagged dependent variable $\left(Y_{i, t-1}\right)$. The coefficient $\beta_{1}$ is expected to be close to 1 . The baseline specification comprises macroeconomic factors, including cost variables (Macro $i, t-1)$, an index for the economic uncertainty (Uncertaintyindexi,t) and the dummy salesi,t. $\mu_{\mathrm{i}, \mathrm{t}}$ are the unnoticed (country specific) effects and $\varepsilon_{i t}$ is the error term.

\footnotetext{
${ }^{8}$ The measures range from credit restrictions, to LTV and DSTI limits and risk weights. For constructing the prudential dummy regulation, we use two databases: (1) Kuttner and Shim (2016), Can non-interest rate policies stabilize housing markets? Evidence from a panel of 57 economies, and (2) the ESRB macroprudential database.

${ }^{9}$ Given the sluggish reduction of NPLs, initiatives for solving these high volumes and for developing an efficient resolution framework emerged (Resolving non-performing loans in Europe, ESRB July 2017).

${ }^{10}$ The NPL Monitor for the CESEE, http://npl.vienna-initiative.com/.
} 
The logit transformation is a standard approach in the literature (Espinoza \& Prasad, 2010; Klein, 2013; Gosh et al., 2015, Beaton et al., 2016). This transformation eliminates the boundary between 0 and 1, and allows capturing the potential nonlinearities between NPLs and explanatory variables.

On top of the baseline specification, the institutional factors and regulations are tested:

$Y_{i, t}=\alpha+\beta_{1} Y_{i, t-1}+\beta_{2} \Delta$ Macro $_{i, t}+\beta_{3} \Delta$ Uncertainty index $_{i, t}+\beta_{4}$ Dummy sales $_{i, t}+$ $\beta_{5}$ Institutional $_{i, t-l}+\beta_{6}$ Dummy regulation $_{i, t-l}+\mu_{i, t}+\varepsilon_{i, t}$

In the third stage, bank sector indicators (Banki,t-l) are evaluated with at most 1 year lag, since for several variables the dynamics are generally stable through time. This addition is desirable, considering that an extensive number of empirical studies focuses on evaluating banks' soundness effect on the quality of portfolios, either at aggregate level (Klein, 2013; Beck et al., 2013; Gosh, 2015), or bank level (Louzis et al., 2012; Neagu et al., 2015).

$Y_{i, t}=\alpha+\beta_{1} Y_{i, t-1}+\beta_{2} \Delta$ Macro $_{i, t}+\beta_{3} \Delta$ Uncertainty index $_{i, t}+\beta_{4}$ Dummy sales $_{i, t}+$ $\beta_{5}$ Institutional $_{i, t-l}+\beta_{6}$ Dummy regulation $_{i, t-l}+\beta_{7}$ Bank $_{i, t-l}+\mu_{i, t}+\varepsilon_{i, t}$

The panel model with fixed effects accounts for omitted country specific characteristics (omitted variable bias) and the unobservable differences among countries, including those on NPL definitions. The GMM estimator solves the dynamic panel bias induced by using the lagged dependent variables, as well as for the endogeneity generated by the pre-determined variables (such as bank specific indicators).

A wide range of GMM estimators were evaluated: a difference estimator proposed by Arellano and Bond, an estimator using the forward ortogonalization proposed by Arrelano and Bover and a system GMM model in one step (Klein, 2013; Gosh, 2015; Beaton et al., 2016), but the system GMM delivers the best results. To mitigate the short time series dimension and the limited number of cross sections, several measures were taken to reduce the number of instruments: using the collapsing method proposed by Holz-Elkin, Newely and Rosen (Roodman, 2009) and imposing a restricted number of lags. Under the GMM specification, the macroeconomic variables are considered strictly exogenous and the bank factors pre-determined (with the exception of money market rates used as a proxy for lending interest rates). The two dummy variables (dummy sales and dummy regulation) are treated as endogenous. The sale of loans is a consequence of the high level of nonperforming loans, while some prudential measures (such as setting borrower limits like loan-to-value, LTV or debt service-to-income, DSTI) are implemented with a view to avoid an increase in NPLs.

For the second part of the analysis, the model that we use is a Panel Structural Bayesian VAR, taking into account the relatively short time period available (2006-2017). In this context, the analysis focuses on an augmented small-macroeconomic model, including: a measure of the economic activity (real GDP growth, annual percentage change), inflation (annual inflation rate), exchange rate (annual variation), interest rate (short-term money 
market rate) and financial sector variables (credit-to-GDP gap ${ }^{11}$ and the household NPL ratio, annual percentage changes). Although other studies include measures for spreads, solvency or other financial variables, data limitations preclude us from analysing the impact of NPL shocks on the aforementioned variables.

The identification of the structural shocks is done using a Choleski factorization, following the mainstream literature on this topic (more recently, Huljak et al., 2020; Klein, 2013; De Bock \& Demyanets, 2012), ordering the variables according to exogeneity - credit and NPL growth, followed by the classical ordering in small macroeconomic models, real GDP growth, inflation, exchange and interest rate. The main argument placing NPLs above the macroeconomic block of variables is that NPLs react more slowly to changes in the macroeconomic environment.

The estimate of the model is done using a hierarchical prior approach, following Jarocinski (2010), in order to account for the heterogeneity present in the cross-country panel. The methodology enriches the model by treating the common coefficients for the mean and covariance of the VAR model as random variables and including them in the estimate process ${ }^{12}$. The prior for $\lambda_{1}$ is an inverse Gamma distribution with small values for shape and scale (i.e., weakly informative calibration, when $\lambda_{1}$ the coefficients for each country come close to their individual estimates, while for very small values the countryspecific coefficients are the same for all countries), while for the other hyper-parameters we choose the standard values used in the literature: $\lambda_{2}=0.5$ and $\lambda_{3}=1$. Running the Gibbs Sampler algorithm yields a stable Panel BSVAR model - all roots of the characteristic polynomial lie inside the unit circle.

\section{Determinants of the NPL ratio for the private sector}

For identifying the determinants of the NPL ratio, we follow three specifications. In the first stage, we test the validity of macroeconomic and cost factors. Given the complexity of the Eurozone and the increasing cross-border banking linkages, favouring contagion during economic or financial contractions, we also include the uncertainty index at the European and global level ${ }^{13}$ as a proxy for external shocks.

\footnotetext{
11 The credit-to-GDP gap is preferred for this exercise as the pre-crisis period is characterized by very high values of nominal credit growth which could negatively affect the stability of the estimates. The credit gap is a natural choice in order to account for both a developing financial sector and identifying potential excessive credit growth.

${ }^{12}$ For technical details, please see the BEAR Toolbox Technical Guide.

${ }^{13}$ World Uncertainty Index, https://www.policyuncertainty.com/wui_quarterly.html
} 
Table 1. Estimate results for the NPL ratios for the private sector ${ }^{14}$

\begin{tabular}{|c|c|c|c|c|c|c|c|c|}
\hline \multirow{3}{*}{$\begin{array}{l}\text { Odds ratio total } \\
\text { (households and non- } \\
\text { financial companies) } t\end{array}$} & \multicolumn{4}{|c|}{$\begin{array}{l}\text { Baseline specification (with } \\
\text { macroeconomic variables) }\end{array}$} & \multicolumn{4}{|c|}{$\begin{array}{l}\text { Baseline specification with institutional } \\
\text { factors }\end{array}$} \\
\hline & \multicolumn{2}{|c|}{$\begin{array}{l}\text { Panel model with } \\
\text { fixed effects^}\end{array}$} & \multicolumn{2}{|c|}{$\begin{array}{c}\text { System GMM } \\
\text { (Blundell and } \\
\text { Bond })^{\wedge \wedge}\end{array}$} & \multicolumn{2}{|c|}{$\begin{array}{l}\text { Panel model with } \\
\text { fixed effects }{ }^{\wedge}\end{array}$} & \multicolumn{2}{|c|}{$\begin{array}{l}\text { System GMM } \\
\text { (Blundell and } \\
\text { Bond })^{\wedge} \wedge\end{array}$} \\
\hline & Model 1 & Model 2 & Model 3 & Model 4 & Model 5 & Model 6 & Model 7 & Model 8 \\
\hline Odds ratio total $\mathrm{t}-1$ & $\begin{array}{l}0.71^{* * *} \\
(0.00)\end{array}$ & $\begin{array}{l}0.77^{* * *} \\
(0.00)\end{array}$ & $\begin{array}{l}0.78^{* * *} \\
(0.00)\end{array}$ & $\begin{array}{l}0.79^{* * *} \\
(0.00)\end{array}$ & $\begin{array}{l}0.72^{* * *} \\
(0.00)\end{array}$ & $\begin{array}{l}0.71^{* * *} \\
(0.00)\end{array}$ & $\begin{array}{l}0.77^{* * *} \\
(0.00)\end{array}$ & $\begin{array}{l}0.75^{* * *} \\
(0.00)\end{array}$ \\
\hline Economic growth ${ }_{t}$ & $\begin{array}{l}-0.07^{* * *} \\
(0.00)\end{array}$ & & $\begin{array}{l}-0.07^{* * *} \\
(0.00)\end{array}$ & & $\begin{array}{l}-0.07^{* * *} \\
(0.00)\end{array}$ & $\begin{array}{l}-0.07^{* * *} \\
(0.00)\end{array}$ & $\begin{array}{l}-0.06^{* * *} \\
(0.00)\end{array}$ & $\begin{array}{l}-0.06^{* * *} \\
(0.00)\end{array}$ \\
\hline$\Delta$ Uncertainty index & 0.00 & 0.00 & -0.00 & 0.00 & 0.00 & 0.00 & 0.00 & 0.00 \\
\hline Europe $_{\mathrm{t}}$ & $(0.93)$ & $(0.13)$ & $(0.67)$ & $(0.16)$ & $(0.83)$ & (0.79) & $(0.75)$ & $(0.70)$ \\
\hline$\Delta$ Real interest rate $\mathrm{t}$ & $\begin{array}{c}0.00 \\
(0.97)\end{array}$ & $\begin{array}{c}0.00 \\
(0.86)\end{array}$ & $\begin{array}{c}0.01 \\
(0.71)\end{array}$ & $\begin{array}{c}0.00 \\
(0.90)\end{array}$ & $\begin{array}{c}0.00 \\
(0.91)\end{array}$ & $\begin{array}{c}0.00 \\
(0.92)\end{array}$ & $\begin{array}{c}0.00 \\
(0.80)\end{array}$ & $\begin{array}{c}0.00 \\
(0.74)\end{array}$ \\
\hline$\Delta$ Unemployment rate $_{\mathrm{t}}$ & & $\begin{array}{l}0.14^{* * *} \\
(0.00)\end{array}$ & & $\begin{array}{l}0.15^{* * *} \\
(0.00)\end{array}$ & & & & \\
\hline $\begin{array}{l}\text { Government } \\
\text { effectiveness } \mathrm{t}-1\end{array}$ & & & & & $\begin{array}{l}-0.43 \\
(0.11)\end{array}$ & & $\begin{array}{c}-0.35^{* * *} \\
(0.00)\end{array}$ & \\
\hline 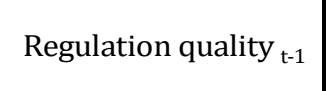 & & & & & & $\begin{array}{c}-0.26 \\
(0.47)\end{array}$ & & $\begin{array}{l}-0.50^{*} \\
(0.05)\end{array}$ \\
\hline Dummy regulation $_{\mathrm{t}}$ & & & & & $\begin{array}{l}-0.12 \\
(0.27)\end{array}$ & $\begin{array}{c}-0.12 \\
(0.26)\end{array}$ & $\begin{array}{c}-0.14 \\
(0.24)\end{array}$ & $\begin{array}{c}-0.14 \\
(0.27)\end{array}$ \\
\hline Constant & $\begin{array}{l}-0.59^{* * *} \\
(0.00) \\
\end{array}$ & $\begin{array}{c}-0.55^{* * *} \\
(0.00) \\
\end{array}$ & $\begin{array}{l}-0.41^{*} \\
(0.05) \\
\end{array}$ & $\begin{array}{l}-0.50^{*} \\
(0.05) \\
\end{array}$ & $\begin{array}{l}-0.29 \\
(0.12) \\
\end{array}$ & $\begin{array}{c}-0.35 \\
(0.17) \\
\end{array}$ & $\begin{array}{l}-0.20^{*} \\
(0.09)\end{array}$ & $\begin{array}{c}-0.02 \\
(0.91) \\
\end{array}$ \\
\hline $\begin{array}{l}\text { Control for the sales } \\
\text { of loans }\end{array}$ & yes & yes & yes & yes & yes & yes & yes & Yes \\
\hline Observations & 119 & 119 & 119 & 119 & 119 & 119 & 11 & 119 \\
\hline No. instruments & & & 11 & 11 & & & 1 & 15 \\
\hline R squared (within) & 0.87 & 0.87 & & & 0.88 & 0.88 & & \\
\hline Hansen test (p-val) & & & 0.11 & 0.26 & & & 0.2 & 0.43 \\
\hline $\operatorname{AR}(1)(p-v a l)$ & & & 0.03 & 0.02 & & & 0.0 & 0.05 \\
\hline$A R(2)(p-v a l)$ & & & 0.92 & 0.42 & & & 0.8 & 0.67 \\
\hline
\end{tabular}

Note. The values present the coefficients of explanatory variables and in parentheses the $\mathrm{p}$-values, where $* \mathrm{p}<$ $0.10,{ }^{* *} \mathrm{p}<0.05,{ }^{* * *} \mathrm{p}<0.01$;

$\Delta$ stands for the first difference operator

$\wedge$ Standard specification for the panel model with country fixed effects, supported by the Hausman test. This approach captures the potential heterogeneity among countries.

$\wedge^{\wedge}$ For endogenous and predetermined variables, the lags are limited to 2 and the collapse method is used. The endogenous variable is the lagged dependent variable, while the cost indicator is considered

${ }^{14}$ Additional controls were tested and found not significant: consumer confidence indicator, inflation rate and loan to deposits. For reasons of space, they are not presented in the paper. The data limitations don't allow a separate pre and post-crisis estimate exercise. 
predetermined. The one step system GMM estimator proposed by Blundell and Bond was used, with instrumental variables in levels.

Source: own estimate.

We notice a persistency of the NPL ratio that ranges between 70 and $80 \%$, justifying the need for the GMM method. Under the baseline specification, the results show that both unemployment and economic growth have an impact on NPLs, an increase in unemployment or an economic contraction leading to an increase in NPLs (Table 1).

The results are similar to the findings in the literature, which show that deterioration in the macroeconomic stance will impair debtors' repayment capacity, leading to an increase in NPLs. The results are similar for both panel models with country fixed effects and the system GMM specification ${ }^{15}$. The unemployment rate is expected to have a higher impact compared to other factors due to both the decrease in cash inflows and the uncertainty surrounding future reintegration in the labour market. Debtors that already face financial problems may find themselves in a more difficult situation if they become unemployed, depending on the difficulties of reintegration in the labour market. The coefficients are in the range of previous findings (Klein, 2013 finds a coefficient around 0.03 on average for GDP growth, but lower for unemployment rates). Cost factors, approximated using the money market rates at 3 months, are not significant for aggregate NPLs. Although costs are relevant for the household portfolio, as the following section shows, for firms, costs are more related to their financial soundness (risk premiums) and the maturity of loans, generally much shorter compared to loans to households. A control for the sale of impaired loans was also included, but the results are not significant and not presented separately. The results for the uncertainty index are inconclusive. The regulation dummy, although has the expected negative effect, is not statistically significant, showing that the macroprudential measures applied to households were probably offset by an increase in corporate lending.

In the second stage, we consider the variables relevant for the institutional framework, for the government effectiveness and regulatory quality and also the prudential regulation. The results show that an improvement in the government effectiveness will contribute positively to the quality of loans, reducing the NPLs (similar to Anastasiou et al., 2019). On average, a 1\% increase in government effectiveness leads to a decrease by $0.3 \%$ in the probability of higher NPLs. Results support the same hypothesis in terms of the quality of regulations. However, prudential regulations applied for the household sector are not relevant for the aggregate NPLs ${ }^{16}$. To capture the impact of these measures, a microeconomic specification would be better suited and this could represent a further pathway for improving this study.

Bank related variables are available at aggregate level for each country. They were used in levels, either contemporaneously or with a lag (Table 2), given their slow change through the analysed period. Another decision taken due to data availability and the

${ }^{15}$ Constraints regarding each methodology remain, such as the high persistency, the endogeneity problem and the large number of instruments.

${ }^{16}$ However, for the household portfolio, the contemporaneous impact of regulations which puts a limit on lending shows that for the periods in which regulation was tightened we see a positive and significant contribution to NPL coming from a decrease in lending. Results are available upon demand. 
efficiency loss generated by the number of instruments was to evaluate each variable independently (similar to Louzis et al., 2012).

Table 2. GMM estimate results for the NPL ratios with banking sector variables

\begin{tabular}{|c|c|c|c|c|c|c|c|c|c|c|}
\hline & Model 1 & Model 2 & Model 3 & Model 4 & Model 5 & Model 6 & Model 7 & Model 8 & Model 9 & Model 10 \\
\hline Odds ratio total ${ }_{\mathrm{t}-1}$ & $\begin{array}{l}0.63^{* * *} \\
(0.00)\end{array}$ & $\begin{array}{l}0.54^{* * *} \\
(0.00)\end{array}$ & $\begin{array}{l}1.20^{* * *} \\
(0.00)\end{array}$ & $\begin{array}{l}0.74^{* * *} \\
(0.00)\end{array}$ & $\begin{array}{l}0.73^{* * *} \\
(0.00)\end{array}$ & $\begin{array}{l}0.92^{* * *} \\
(0.00)\end{array}$ & $\begin{array}{l}0.85^{* * *} \\
(0.00)\end{array}$ & $\begin{array}{l}0.75^{* * *} \\
(0.00)\end{array}$ & $\begin{array}{l}0.79^{* * *} \\
(0.00)\end{array}$ & $\begin{array}{l}0.73^{* * *} \\
(0.00)\end{array}$ \\
\hline LTD $_{t-2}$ & $\begin{array}{l}0.01^{* *} \\
(0.03)\end{array}$ & & & & & & & & & \\
\hline Credit/GDP ${ }_{\mathrm{t}-2}$ & & $\begin{array}{l}0.02^{* * *} \\
(0.01)\end{array}$ & & & & & & & & \\
\hline $\begin{array}{c}\text { Credit growth rate t- } \\
2\end{array}$ & & & $\begin{array}{l}0.02^{* * *} \\
(0.00)\end{array}$ & & & & & & & \\
\hline ROA t-1 & & & & $\begin{array}{l}-0.06^{* * *} \\
(0.01)\end{array}$ & & & & & & \\
\hline ROE t-1 & & & & & $\begin{array}{l}-.005^{* *} \\
(0.03)\end{array}$ & & & & & \\
\hline Capital /assets $\mathrm{t}_{\mathrm{t}-1}$ & & & & & & $\begin{array}{l}-0.11^{* *} \\
(0.01)\end{array}$ & & & & \\
\hline Above average & & & & & & & -0.09 & & & \\
\hline Capital/assets $_{\mathrm{t}-1}$ & & & & & & & $(0.13)$ & & & \\
\hline $\begin{array}{l}\text { Below average } \\
\text { Capital/assets }\end{array}$ & & & & & & & $\begin{array}{l}-0.08^{*} \\
(0.07)\end{array}$ & & & \\
\hline $\begin{array}{c}\text { NPL coverage ratio t } \\
1\end{array}$ & & & & & & & & $\begin{array}{l}-0.01^{* * *} \\
(0.01)\end{array}$ & & \\
\hline Non interest income & & & & & & & & & -0.01 & \\
\hline $\mathrm{t}-1$ & & & & & & & & & $(0.40)$ & \\
\hline Bank Z-score $_{\mathrm{t}-1}$ & & & & & & & & & & $\begin{array}{c}-0.10^{* * *} \\
0\end{array}$ \\
\hline Constant & $\begin{array}{l}-1.47^{* *} \\
(0.01) \\
\end{array}$ & $\begin{array}{c}-1.70^{* * *} \\
(0.00)\end{array}$ & $\begin{array}{c}0.36 \\
(0.11) \\
\end{array}$ & $\begin{array}{c}-0.24^{* *} \\
(0.01)\end{array}$ & $\begin{array}{c}-0.26^{* *} \\
(0.01)\end{array}$ & $\begin{array}{l}1.48^{* * *} \\
(0.00)\end{array}$ & $\begin{array}{l}1.03^{*} \\
(0.05) \\
\end{array}$ & $\begin{array}{c}0.61^{*} \\
(0.05) \\
\end{array}$ & $\begin{array}{c}0.07 \\
(0.84) \\
\end{array}$ & $\begin{array}{c}0.50^{*} \\
(0.09) \\
\end{array}$ \\
\hline $\begin{array}{c}\text { Economic \& } \\
\text { institutional controls }\end{array}$ & Yes & Yes & Yes & Yes & Yes & Yes & Yes & Yes & Yes & Yes \\
\hline Cost factors control & No & No & No & No & No & No & No & No & No & No \\
\hline $\begin{array}{c}\text { Control for the sales } \\
\text { of loans }\end{array}$ & Yes & Yes & Yes & Yes & Yes & Yes & Yes & Yes & Yes & Yes \\
\hline Observations & 133 & 135 & 122 & 135 & 135 & 119 & 119 & 129 & 135 & 134 \\
\hline No. instruments & 11 & 11 & 11 & 11 & 11 & 11 & 14 & 11 & 11 & 11 \\
\hline Hansen test (p-val) & 0.17 & 0.13 & 0.34 & 0.17 & 0.11 & 0.15 & 0.13 & 0.14 & 0.14 & 0.17 \\
\hline $\mathrm{AR}(1)(\mathrm{p}$-val) & 0.04 & 0.05 & 0.03 & 0.02 & 0.03 & 0.03 & 0.03 & 0.03 & 0.03 & 0.07 \\
\hline AR(1) (p-val) & 0.49 & 0.66 & 0.72 & 0.94 & 0.95 & 0.95 & 0.96 & 0.49 & 0.74 & 0.73 \\
\hline
\end{tabular}

Note. The values present the coefficients of explanatory variables and in parentheses the p-values, where $* \mathrm{p}<$ $0.10,{ }^{* *} \mathrm{p}<0.05,{ }^{* * *} \mathrm{p}<0.01$;

In order to limit the number of instruments, for endogenous and predetermined variables, the lags are limited to 2 and the collapse method is used. The endogenous variable is the lagged dependent variable, while the bank indicators are considered pre-determined. The instrumental variables were used in levels.

Source: own estimate. 
Firstly, for testing Keeton's lax credit standard hypothesis, we used: loan to deposits ratio (LTD), the growth ratios for credit and credit to GDP. The results show that lending dynamics affect NPL ratios and their effect is noticed after minimum two years' time. Countries with higher credit to GDP ratio or with higher loan-to-deposit ratios seem to be more vulnerable to extreme shocks and witness increases in NPLs. The theory seems to be supported by the credit growth ratio as well, but the results might be instable due to the large autocorrelation identified (1.2 for the lag of the dependent variable).

In terms of profitability, results show that the more profitable the banking system (higher ROA), the better the risk management and the lower the NPL ratios in the future (on average by $6 \%$ lower), confirming the bad management hypothesis. The use of an alternative measure (ROE) supports the results, which are similar to those of Klein (2013), a 10\% increase in ROE leads to a $0.5 \%$ increase in odds ratio. The net interest margin as a measure of costs efficiency was, however, not found to be significant.

The same is true for the level of capitalization ${ }^{17}$ : better capitalized banks are generally facing lower NPLs, a 1 percentage point increase in the capital to assets ratio leading to $11 \%$ decrease in the odds ratio similar to Louzis et al. (2012) and Gosh(2015). This supports the view that better capitalized banks will not opt for high risk investments, because they are not bearing the risks (moral hazard). However, if we split between low and high capitalized banking systems (banks with lower or higher than average capital ratios), we see that when banks have a higher than average ratio, this contributes to a decrease in NPLs, while for those below average the results are not statistically confirmed.

The NPL coverage ratios (the value of provisions to the volume of non-performing loans) and the Z-score for the banking system ${ }^{18}$ work in the same direction. When banks already face difficulties and act to cover the potential losses (high NPL coverage ratio), they avoid taking additional risks. However, Gosh (2015) finds evidence for a positive relationship between coverage ratios and NPLs. Additionally, the diversification theory is not relevant for the countries in the current sample. This can be explained by the fact that for these countries, the banking sector main activities relate to lending and to a lesser extent to other activities. Similar to Louzis et al. (2012) and Gosh (2015), diversification was captured in terms of non-interest income to total income.

\section{Panel VAR}

In order to capture the impact of exogenous shocks on NPLs in the real economy, we estimate a reduced-form model using a panel of EEC countries similar to that employed in the first part of the analysis and the NPL ratio for the household sector. The countries included in the sample (Czech Republic, Hungary, Poland and Romania) experience relatively similar pre- and post-crisis dynamics, while financial data scarcity is an inherent issue when considering countries from the EEC region. Using the estimated coefficients and structural shocks, we build the impulse-response functions (IRF) and forecast error

\footnotetext{
${ }^{17}$ Similar results were obtained for the solvency ratio.

${ }^{18}$ According to the World Bank Global financial development database, the indicator captures the probability of failure of a country's commercial banking system, comparing the buffer of a country's commercial banking system (capitalization and returns) with the volatility of those returns.
} 
variance decompositions (FEVD) to study the impact of exogenous NPL shocks on the macro-financial variables included in the model.

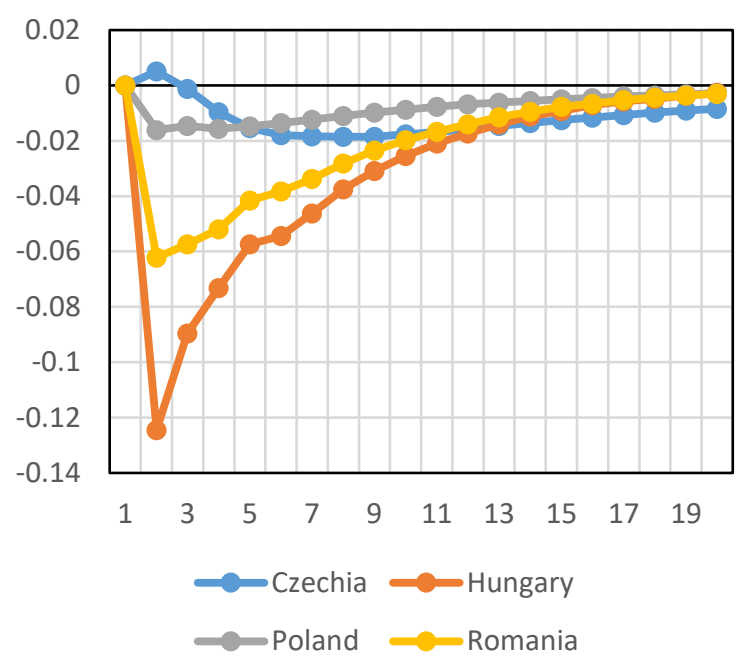

Figure 2. Response of credit gap to NPL shock

Source: own estimate.

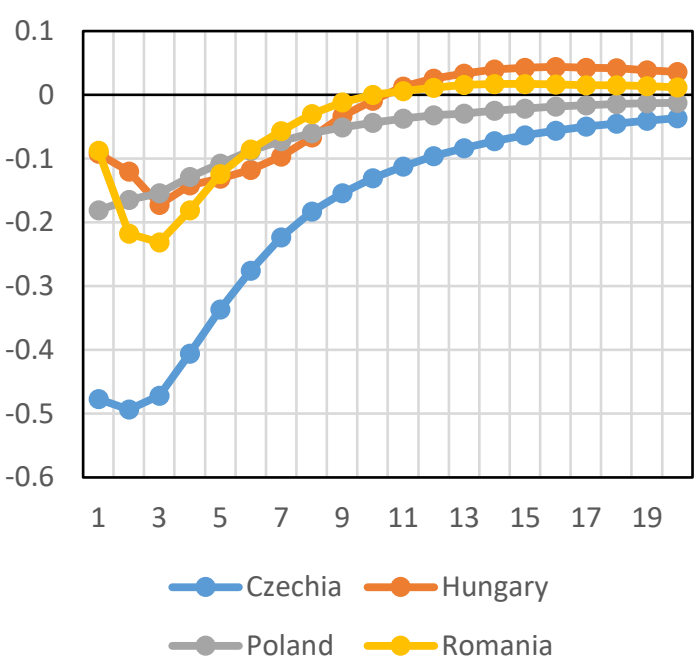

Figure 3. Response of GDP growth to NPL shock

Source: own estimate.

Results vary significantly between countries in most cases. A sudden increase in NPLs will initially diminish the credit-to-GDP gap rather significantly in Hungary and somewhat less significantly in Romania, but the effect seems transitory, as it vanishes almost entirely after around two years. Meanwhile, the impact is almost negligible in the case of the Czech Republic and Poland, suggesting that the two variables involved co-move in a similar fashion. On the other hand, the response of GDP alone is considerable in the case of the Czech Republic, implying that both economic activity and credit contract substantially following an NPL shock. The response of the real activity is more muted for the other three economies, and exhibits a lower persistency as well. The results for the impact of NPL shocks on economic growth are similar in terms of magnitude to other studies such as those of Huljak et al. (2020), Klein (2013) and Espinoza and Prasad (2010).

We turn our attention to the response of NPL to other shocks included in the model, such as aggregate demand (GDP growth) and monetary policy shocks, as a feedback mechanism between the real economy and the financial sector, but also as a cross-check to the panel approach described in the first section. 


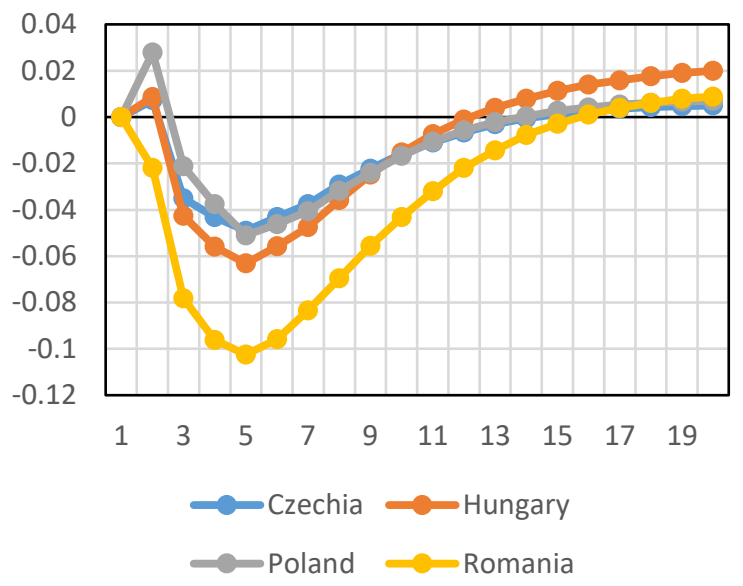

Figure 4. Response of NPL growth to aggregate demand (positive GDP growth) shock Source: own estimate.

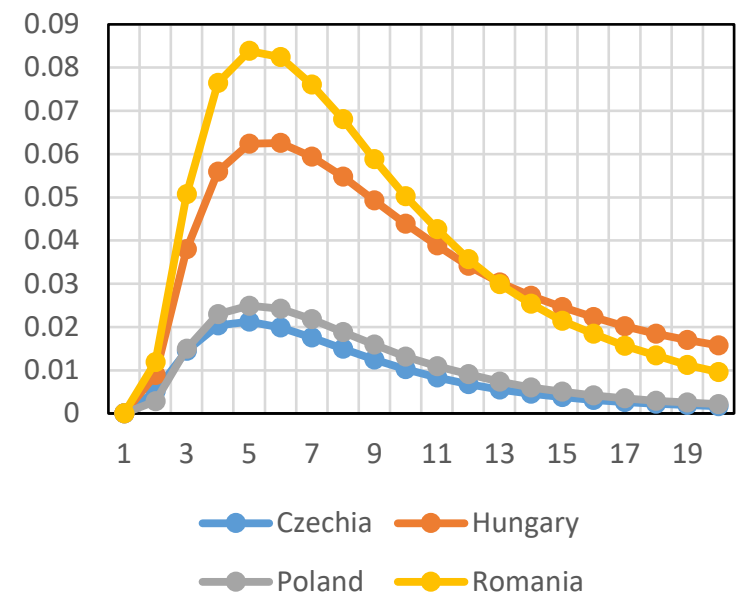

Figure 5. Response of NPL growth to monetary policy (interest rate) shock

Source: own estimate.

Responses of NPLs to a demand shock are mostly similar across countries, with a somewhat more pronounced decline in the case of Romania, and a moderate degree of persistency. It is worth mentioning that in most cases, after the initial shock, NPL growth actually accelerates in the following quarter before declining. Finally, an interest rate shock has, as expected, an opposite effect, with Romania and Hungary standing out as the cases with the most sizeable response of NPL growth as well as a high persistence thereof.
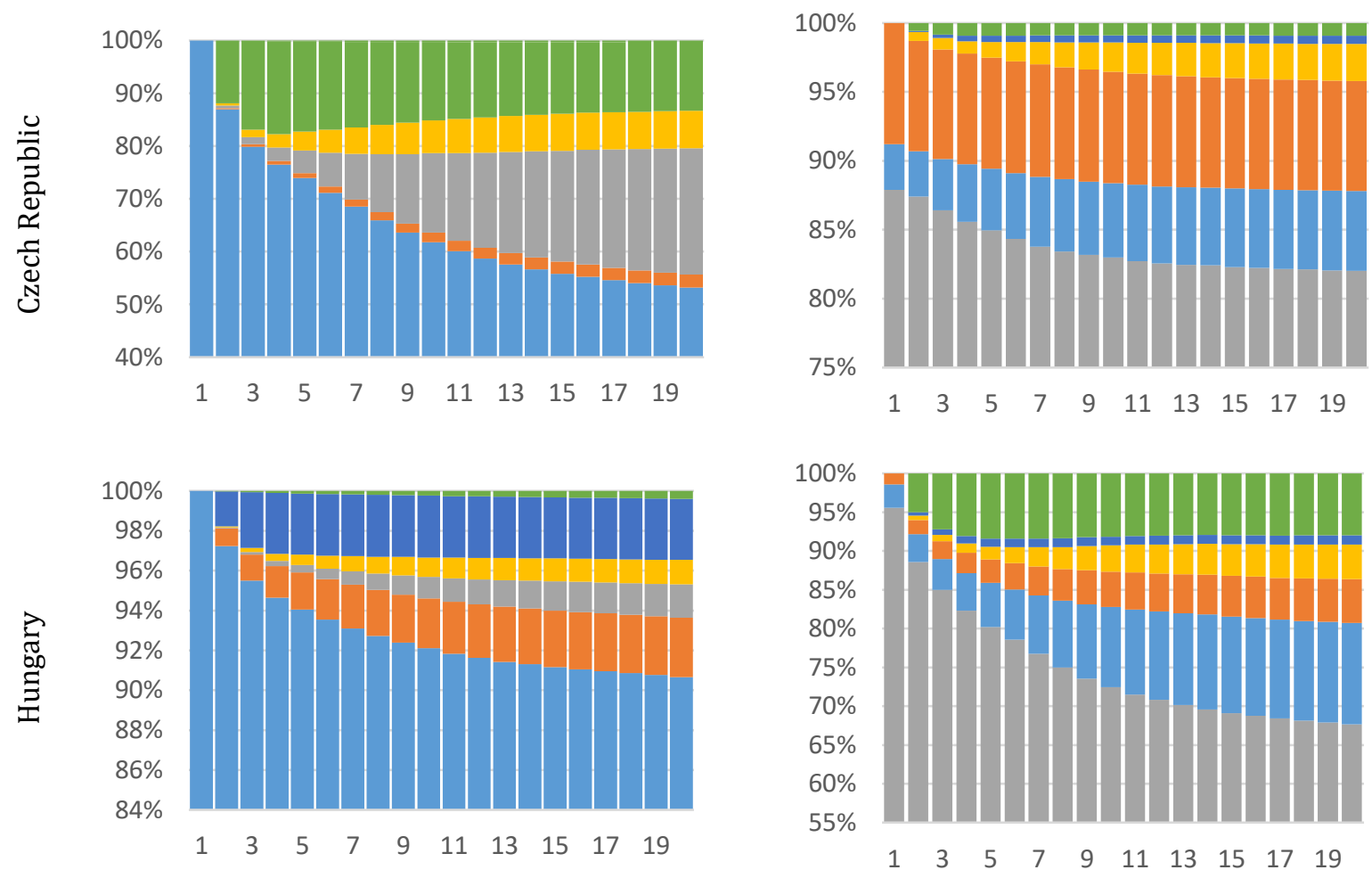

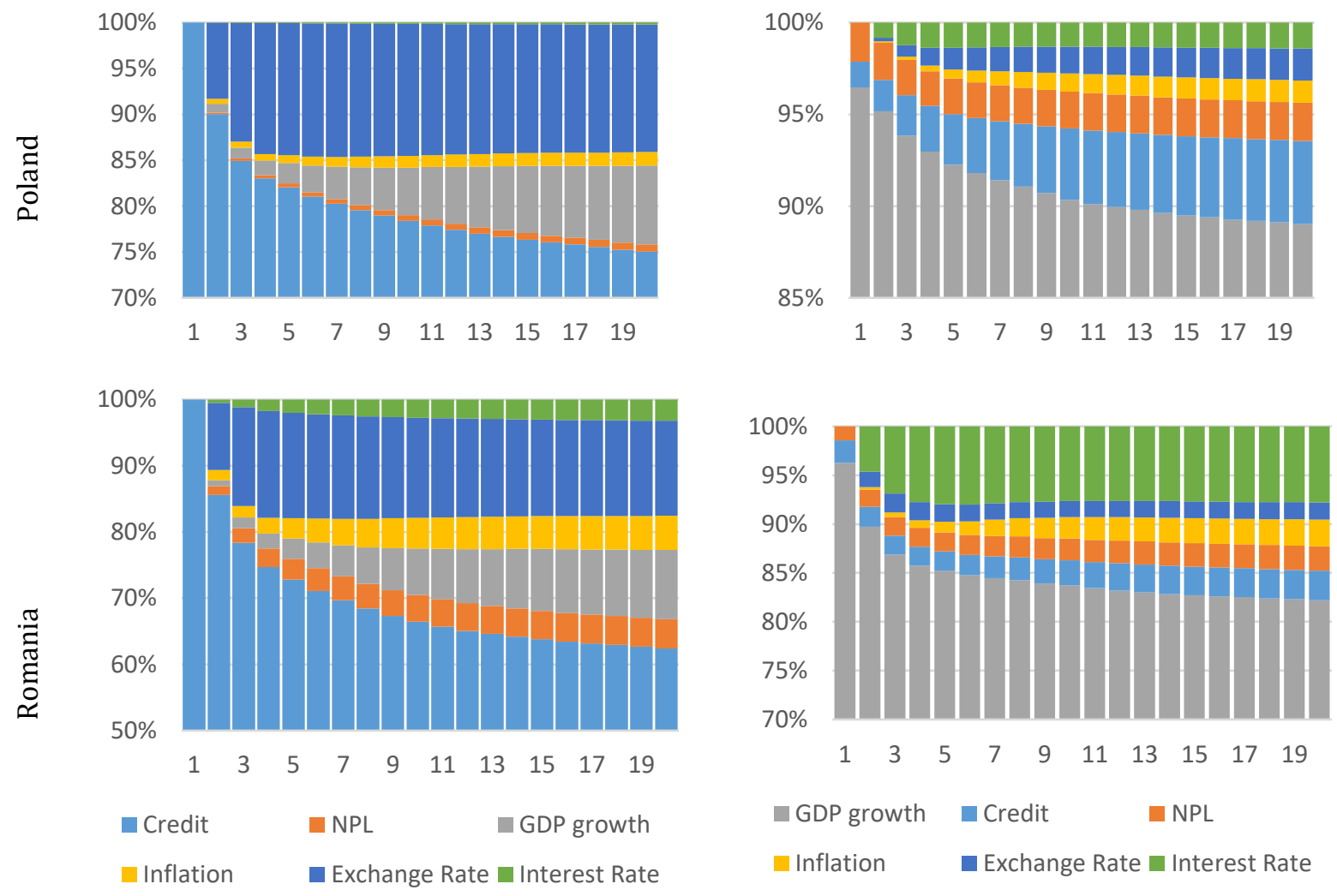

Figure 6. Forecast Error Variance Decomposition (FEVD) - Credit gap Source: own estimate.

Figure 7. Forecast Error Variance Decomposition (FEVD) - GDP growth

Source: own estimate.

In the case of the credit gap, the exchange rate is by far the most important variable in explaining variation, with values around $14 \%$ for all countries, except for Hungary. It is followed by the inflation rate with about $3 \%$ of the variation, most importantly in the Czech Republic and less important in the other three countries. NPLs hold a small part in explaining the credit gap, accounting for only $2 \%$ of its variation, most notably in Romania, around 3.5\%. Turning to economic growth, credit becomes the most relevant factor in explaining GDP developments, but only accounts for around 5\% of variation under this specification. NPL is more important here, explaining approximately $4 \%$ of GDP growth across the four countries, in line with other empirical studies on this topic (more recently, Huljak et al., 2020 or Espinoza \& Prasad, 2010).

\section{Conclusions and Policy Implications}

The improvement of the regulatory framework is a task that should adapt rapidly to the changing nature of risks. As such, for the credit risk, it is essential to understand what impairs debtors' repayment capacity in order to set the appropriate prudential measure to increase debtors' resilience to shocks.

This study attempted to shed some light on the determinants of NPL ratios for a sample of Eastern European countries. The results support the findings in the empirical literature and show that adverse macroeconomic developments and previous lending 
dynamics are associated with high NPL ratios. The largest impact comes from the unemployment and could be also a result of labour market rigidities, frequent during crises episodes in emerging market economies.

In terms of credit dynamics, we notice that countries with higher credit dynamics in the past witnessed higher NPLs later. Although these dynamics take time to materialize, policy makers should not disregard the credit cycle. Moreover, the fact that credit risk is the legacy of bad credit booms should be on the policy agenda. Another relevant finding refers to the role of institutional variables, such as the government effectiveness, which contribute positively to the quality of bank portfolios.

Banking sector variables plead for the fact that better management can translate into lower risk, while also better capitalized banks seem to not have the incentives to invest in riskier assets. However, an aggregate evaluation could hide some heterogeneity, as it was proven that if the banking system will put a level of capital above the average, it will indeed be more prudent. The same could not be proven for less than average capitalized banks. Supervisors should therefore put higher importance on the quality of the management and not lose sight of the microprudential approach.

Regarding the macroprudential measures, the limits on indebtedness (debt serviceto-income, DSTI or loan-to-income, LTI) and on the collateral value (loan-to-value, LTV) were extensively used by the authorities in the analysed countries. Their effect at the aggregate level of NPL ratios however is not relevant and more work is needed for a better identification, such as a microeconomic approach. Nevertheless, we consider that using these measures could increase the resilience of borrowers when facing external shocks, as well as they can temper the credit cycle.

The second approach complements some of these findings. In order to capture the impact of exogenous shocks on NPLs in the real economy, we estimate a reduced-form model (Bayesian Structural PVAR) using a similar panel of EEC countries. We notice that the feedback from NPLs to the real activity and credit growth varies significantly among countries. A sudden increase in NPLs will initially diminish the credit-to-GDP gap, but the effect is rather transitory. The response of real activity to such increases in NPLs exhibits a lower persistency as well. The results for the impact of NPL shocks on economic growth are similar in terms of sign and magnitude to other studies such as those by Huljak et al. (2020), Klein (2013) and Espinoza and Prasad (2010).

While the paper explores the link between NPLs and the real economy in the case of EEC countries, an important topic for policy-makers as well as researchers, it should be noted that the estimate robustness is limited by data availability constrains naturally associated with the development of the EEC financial sectors. This important limitation is highlighted throughout the study, while various econometric techniques and model specifications are included in order to mitigate most factors that could negatively affect the estimate results.

\section{References}

Accornero, M., Alessandri, P., Carpinelli, L., \& Sorrentino, A.M. (2017). Non-performing loans and the supply of bank credit: evidence from Italy.Questioni di Economia e Finanza (Occasional Papers) 374. Retrieved from https://papers.ssrn.com/sol3/papers.cfm?abstract_id=2954995. 
Anastasiou, D., Louri, H.,\& Tsionas, M. (2016). Non-Performing Loans in the Euro Area: Are Core-Periphery Banking Markets Fragmented? Bank of Greece Working Paper Series, No. 219. Retrieved from https://onlinelibrary.wiley.com/doi/abs/10.1002/ijfe.1651.

Anastasiou, D., Bragoudakis, Z., \& Malandrakis, I. (2019). Non-performing loans, governance indicators and systemic liquidity risk: evidence from Greece .Bank of Greece WP, No.260. Retrieved from https://papers.ssrn.com/sol3/papers.cfm?abstract_id=3674861.

Ari, A., Chen, S., \& Ratnovski, L. (2019). The Dynamics of Non-Performing Loans During Banking Crises: A New Database.IMF WP no.272. Retrieved from https://www.imf.org/en/Publications/WP/Issues/2019/12/06/The-Dynamics-ofNon-Performing-Loans-during-Banking-Crises-A-New-Database48839\#: :text=We\%20find\%20a\%20close\%20relationship,severity\%20of\%20post \%2Dcrisis\%20recessions.\&text=0ur\%20findings\%20suggest\%20that\%20reducing, for\%20post\%2Dcrisis\%20output\%20recovery.

Bayar, Y. (2019). Macroeconomic, Institutional and Bank-Specific Determinants of NonPerforming Loans in Emerging Market Economies: A Dynamic Panel Regression Analysis. Journal of Central Banking Theory and Practice, 3, 95-110.

Beaton, K., Myrvoda, A., \& Thompson, S. (2016). Non-performing loans in ECCU: Determinants and macroeconomic impact. IMF WP No.229. Retrieved from https://www.imf.org/external/pubs/ft/wp/2016/wp16229.pdf.

Beck, R., Jakubik, P., \& Piloiu, A. (2013). Non-performing loans. What matters in addition to the economic cycle?. ECB WP No.1515. Retrieved from https://www.ecb.europa.eu/pub/pdf/scpwps/ecbwp1515.pdf

Berger, A., \& DeYoung, R. (1997). Problem loans and cost efficiency in commercial banks. Journal of Banking and Finance, 21, 849-870.

Cerutti, E., Claessens, S., \& Laeven, L. (2017). The use and effectiveness of macroprudential policies: New evidence. Journal of Financial Stability, 28, 203-224.

Claessens, S., Kose, A., \& Terrones, M. (2011). Financial Cycles: What? How? When?. International Monetary Fund, IMF Working Paper No.76. Retrieved from https://www.imf.org/en/Publications/WP/Issues/2016/12/31/Financial-CyclesWhat-How-When-24775.

De Bock, R., \& Demyanets, A. (2012). Bank Asset Quality in Emerging Markets: Determinants and Spillovers. IMF Working Paper WP/12/71. Retrieved from https://www.imf.org/external/pubs/ft/wp/2012/wp1271.pdf.

Detken, C., Weeken, O., Alessi, L., Bonfim, D., Boucinha, M., Castro, C., Frontczak, S., Giordana, G., Giese, J., Jahn, N., Kakes, J., Klaus, B., Lang, J., Puzanova, N., \& Welz, P. (2014). Operationalising the countercyclical capital buffer: indicator selection, threshold identification and calibration options. ESRB OP No. 5. Retrieved from https://ideas.repec.org/p/srk/srkops/20145.html.

Espinoza, R., \& Prasad, A. (2010). Nonperforming Loans in the GCC Banking System and their Macroeconomic Effects. IMF WP No.224. Retrieved from https://www.imf.org/external/pubs/ft/wp/2010/wp10224.pdf.

European Systemic Risk Board(2017). Resolving non-performing loans in Europe. Retrieved from 
https://www.esrb.europa.eu/pub/pdf/reports/20170711_resolving_npl_report.en.p df.

Gosh, A. (2015). Banking-industry specific and regional economic determinants of nonperforming loans: Evidence from US states.Journal of Financial Stability, 20, 93-104.

Fell, J., Grodzicki, M., Martin, R., \& O’Brien, E. (2016). Addressing market failures in the resolution of non-performing loans in the euro area. Financial Stability Review, November, 134-146.

Fell, J., Grodzicki, M., Krušec, D., Martin, R., \& O’Brien, E. (2017). Overcoming NonPerforming Loan Market Failures with Transaction Platforms.Financial Stability Review, European Central Bank, 2, 130-144.

Jakubík, P., \&Reininger, T. (2014). What Are the Key Determinants of Nonperforming Loans in CESEE? Institute of Economic Studies, Faculty of Social Sciences Charles University in Prague WP No.26. Retrieved from https://ideas.repec.org/p/fau/wpaper/wp2014_26.html.

Jarocinski, M. (2010). Responses to monetary policy shocks in the east and the west of Europe: a comparison. Journal of Applied Econometrics, 25(5), 833-868.

Jiménez, G., \&Saurina, J. (2006). Credit Cycles, Credit risk and prudential regulation.Bank of Spain, WP No. 0531. Retrieved from https://www.ijcb.org/journal/ijcb06q2a3.htm.

Keeton, W. R. (1999). Does Faster Loan Growth Lead to Higher Loan Losses?. Federal Reserve Bank of Kansas City Economic Review,57-75.

Klein, N. (2013). Non-Performing Loans in CESEE: Determinants and Impact on Macroeconomic Performance. IMF WP No.72. Retrieved from https://www.imf.org/en/Publications/WP/Issues/2016/12/31/Non-PerformingLoans-in-CESEE-Determinants-and-Impact-on-Macroeconomic-Performance-40413.

Louzis, D. P., Vouldis, A. T., \& Metaxas, V. L. (2012). Macroeconomic and bank-specific determinants of non-performing loans in Greece: A comparative study of mortgage, business and consumer loan portfolios. Journal of Banking \& Finance, 36, 1012-1027.

Maciej, G., Laliotis, D., Leber, M., Martin, R., O’Brien, E., \& Zboromirski, P (2015). Resolving the Legacy of Non-Performing Exposures in Euro Area Banks. Financial Stability Review, 1, 146- 154.

Messai, A.S., \& Jouini, F. (2013). Micro and Macro Determinants of Non-performing Loans.International Journal of Economics and Financial Issues, 3(4), 852-860.

Neagu, F., Tatarici, L., \& Mihai, I. (2015). Implementing Loan-to-Value and Debt Service-ToIncome measures: A decade of Romanian experience.NBR OP No.15. Retrieved from https://ideas.repec.org/p/pra/mprapa/65988.html.

Nkusu, M. (2011). Nonperforming Loans and Macrofinancial Vulnerabilities in Advanced Economies. IMF Working Paper WP/11/161. Retrieved from https://www.imf.org/external/pubs/ft/wp/2011/wp11161.pdf.

Pesola, J. (2007). Financial fragility, macroeconomic shocks and banks' loan losses: evidence from Europe.Bank of Finland Research, Discussion Papers 15.Retrieved from https://www.researchgate.net/publication/5094079_Financial_Fragility_Macroecon omic_Shocks_and_Banks'_Loan_Losses_Evidence_from_Europe.

Roodman, D. (2009). How to do xtabond2: An introduction to difference and system GMM in Stata. Stata Journal, 9(1), 86-136.

Skarica,B. (2014) . Determinants of non-performing loans in Central and Eastern European countries.Financial theory and practice, 38 (1), 37-59. 
Vienna Initiative. 2016-2018. NPL Monitor for the CESEE region, http://npl.viennainitiative.com/

Zeqiraj, V., Hammoudeh, S., Iskenderoglu, O., \&Tiwari, A.K. (2020). Banking sector performance and economic growth: evidence from Southeast European countriesPost-Communist Economies, 32(2), 267-284. 
Annex 1. Stylized facts

Table 1. Summary statistics

\begin{tabular}{|l|c|c|c|c|c|}
\hline Variable & Obs. & \multicolumn{1}{l}{ Mean } & Std. Dev & Min & Max \\
\hline $\begin{array}{l}\text { NPL ratio household } \\
\text { sector* }\end{array}$ & 312 & 6.46 & 5.33 & 0.18 & 20.06 \\
\hline NPL ratio & 156 & 8.00 & 5.92 & 0.2 & 24 \\
\hline Credit /GDP & 156 & 53.38 & 16.43 & 20.06 & 104.56 \\
\hline Credit growth & 148 & 10.257 & 18.57 & -17.25 & 72.57 \\
\hline $\begin{array}{l}\text { Uncertainty index } \\
\text { Europe }\end{array}$ & 156 & 145.0 & 47.47 & 90.08 & 243.31 \\
\hline GDP growth & 156 & 2.69 & 4.32 & -15.8 & 11.9 \\
\hline Unemployment rate & 156 & 10.09 & 4.38 & 3.9 & 23.99 \\
\hline Inflation rate & 154 & 3.07 & 3.01 & -1.6 & 15.3 \\
\hline Money market rate 3M & 137 & 2.89 & 2.89 & -0.33 & 13.09 \\
\hline Loan to deposits (LTD) & 152 & 113.14 & 34.35 & 55.92 & 257.32 \\
\hline ROA & 156 & 0.78 & 1.63 & -10.47 & 4.24 \\
\hline ROE & 156 & 7.51 & 16.43 & -117.67 & 38.47 \\
\hline Capital to assets & 133 & 10.33 & 3.67 & 5.4 & 23.6 \\
\hline Solvency ratio & 147 & 16.72 & 4.53 & 10.1 & 35.65 \\
\hline $\begin{array}{l}\text { Non-interest } \\
\text { income/Total income }\end{array}$ & 156 & 39.59 & 10.87 & 21.46 & 74.10 \\
\hline NPL coverage ratio & 141 & 62.09 & 27.46 & 14.4 & 153.6 \\
\hline Bank Z-score & 155 & 8.21 & 4.240 & 1.01 & 18.64 \\
\hline $\begin{array}{l}\text { Government } \\
\text { effectiveness }\end{array}$ & 156 & 0.59 & 0.42 & -0.36 & 1.19 \\
\hline Quality of regulation & 156 & 0.82 & 0.41 & -0.58 & 1.69 \\
\hline
\end{tabular}

Note: * quarterly frequency variable available for Bulgaria, Czech Republic, Estonia, Hungary, Poland and Romania

Source: Eurostat, World Bank, IMF, central banks' websites. 


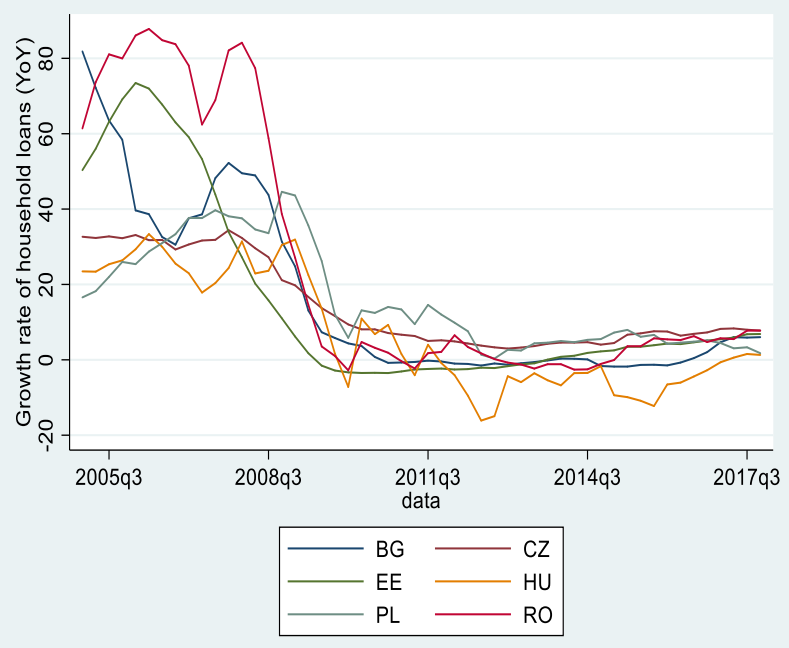

Figure 1. Growth rate of household loans (YoY)

Source: own calculations.

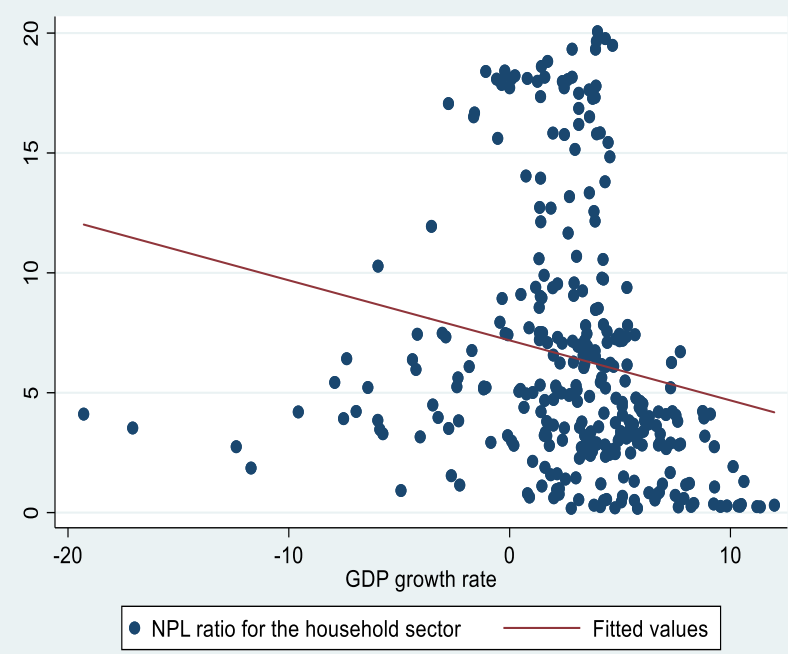

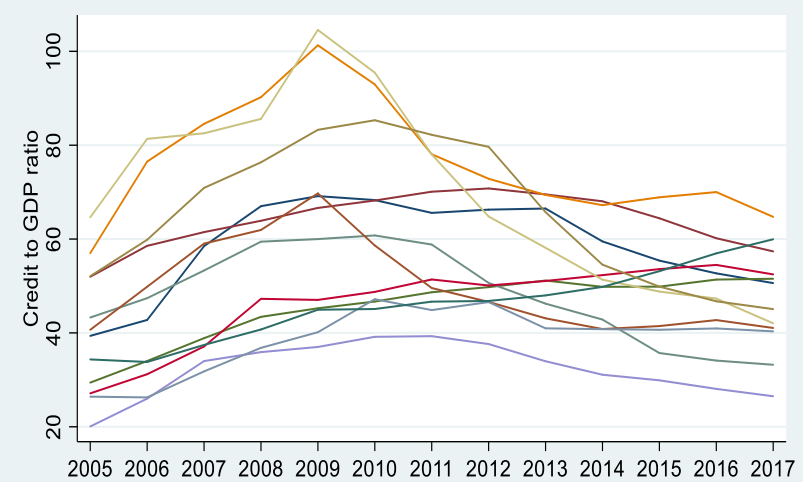

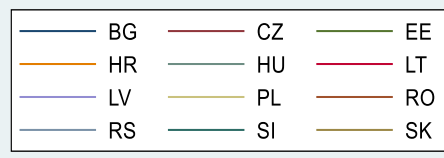

Figure 2. Private credit to GDP ratio (households and non-financial companies)

Source: own calculations.

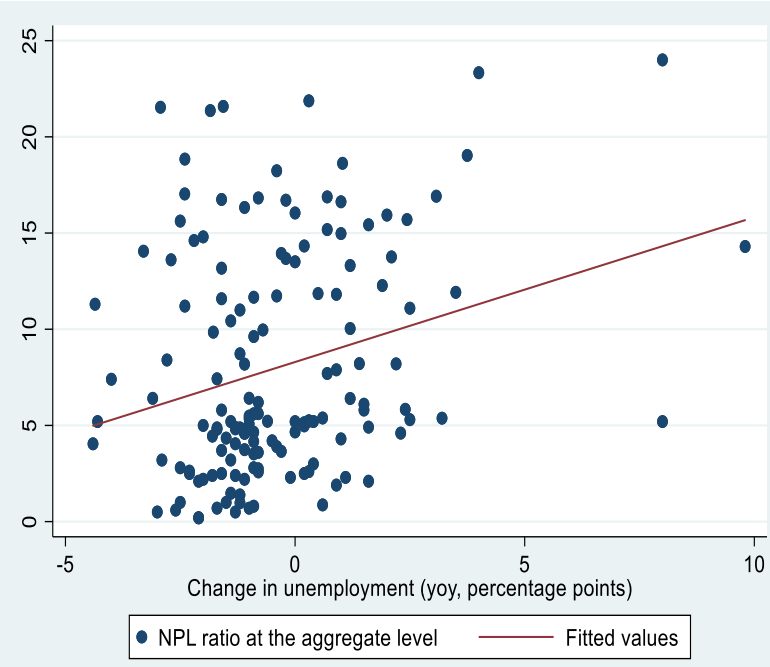

Figure 3. Correlation between the NPL ratio, GDP and unemployment

Source: own calculations. 